\title{
The Directions and Names of the Winds
}

[Aristotle], Ventorum situs et nomina

by

\author{
Alan C. Bowen \\ Institute for Research in \\ Classical Philosophy and Science \\ bowen@IRCPS.org
}




\begin{abstract}
The anonymous text Ventorum situs et nomina, once held to be by Aristotle himself, gives the local names of 10 topic winds as well as their directions. It is not an elaboration of the wind-rose that Aristotle, for example, describes in Meteor. 2.5, though many scholars have assumed this, but a presentation

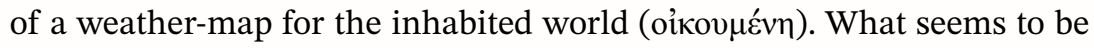
important to the author in collecting the local winds under the topic winds is not so much their direction as their time of year as well as the etymologies of the local names.

About the Author

ALAN C. BOWEN is director of the Institute for Research in Classical Philosophy and Science (Baysville, ON, Canada). He is the author of numerous articles and books focused mainly on the history of Hellenistic science, especially astronomy, and philosophy. His latest book, with Francesca Rochberg, is Hellenistic Astronomy: The Science in Its Contexts (Brill, 2020), listed as an Outstanding Academic Title of 2020 by Choice/Choice Review.
\end{abstract}


$\mathbf{T}$

his brief, anonymous account of the winds, which has no explanatory introduction and a laconic conclusion, is perhaps best described as a Hellenistic contribution to a body of learning about the winds, weather, and signs to which many contributed in antiquity, including notably Aristotle and Theophrastus.

1. The subject of the Vent. situs

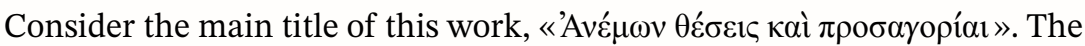
word « $\theta \dot{\varepsilon} \sigma 1 \varsigma »$, like the Latin "situs", though usually rendered into English in this context by "location", "position", ${ }^{2}$ or "situation", ${ }^{3}$ has the general sense "disposition". But, in the case of the winds, especially as presented in this account, the disposition in question is surely a direction. Hence, I translate the Greek title as "The Directions and Names of the Winds". This is consistent with, and appropriate to, the substance of Aristotle's Meteor.

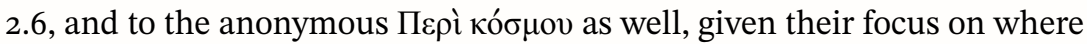
the winds are from. ${ }^{4}$ I will return to this in due course.

\section{On its provenance}

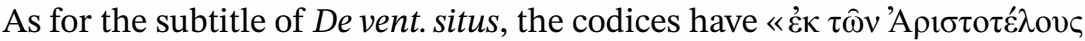

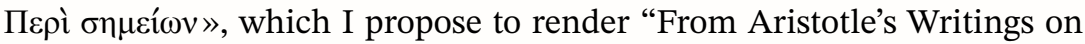
Signs". ${ }^{5}$ But perhaps this should really be "From Aristotle's Treatise On Signs" instead. In either case, the implication is that it was not Aristotle himself who offered the remarks in Vent. situs but some later author. Of

1 See D’Avella 2007, 223.

${ }^{2}$ In French, see Federspiel and Levet 2018, 28, 83.

3 See Hett 1936, 453.

4 Aristotle himself maintains that air in motion counts as wind when it is understood to flow from a source or origin [Meteor. 360a27-33: for the text transposed, see Lee

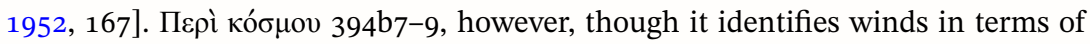
their direction, defines wind itself simply as the flow of a connected mass of air.

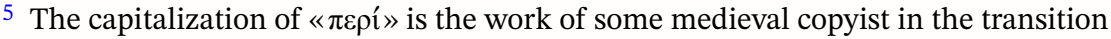
from majuscules to minuscules and so has no probative value in its own right. 
course, in either case again, the question becomes, In what sense is the $D e$ vent. situs really from its source? Is it

(a) an abridgment, that is, a complete section of this source?

(b) a collection of passages taken from throughout that source? or

(c) indebted to its source in the more limited sense that it draws on some governing motif or project that is developed in ways not found in the source? ${ }^{6}$

Now, I will not tarry with speculation about who this author was, whether he was a Peripatetic, a Stoic, or whatever. Nor will I address the related

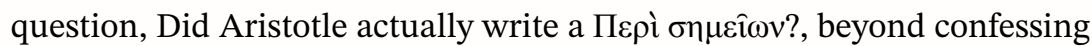
that, in my view, the evidence is not of the sort that warrants the claim that

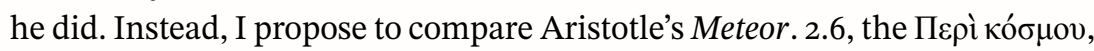
and the Ventorum situs, with the aim of highlighting two features by which the latter differs significantly from the other accounts of the winds, features that should, but do not, figure in recent discussions of its provenance.

\begin{tabular}{cc} 
Latitude North $\left(\varphi^{\circ}\right)$ & $\begin{array}{c}\text { Distance }\left(\eta^{\circ}\right) \\
\text { from SSRP to VERP }\end{array}$ \\
\hline $0^{\mathrm{a}}$ & 23.5 \\
$23.5^{\mathrm{b}}$ & 25.77 \\
37.1 & 30 \\
45 & 34.33 \\
55.67 & 45 \\
60 & 52.89 \\
$66.5^{\mathrm{c}}$ & 90
\end{tabular}

a The latitude at the equator.

b The northern limit of the torrid zone.

c The Sun touches the horizon but does not cross it.

Table 1. The variation of the distance of the summer solstitial rising point (SSRP) to the vernal equinoctial rising point (VERP).

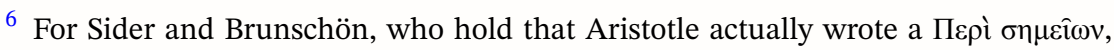
only the first two possibilities are in play $[2007,12]$. 


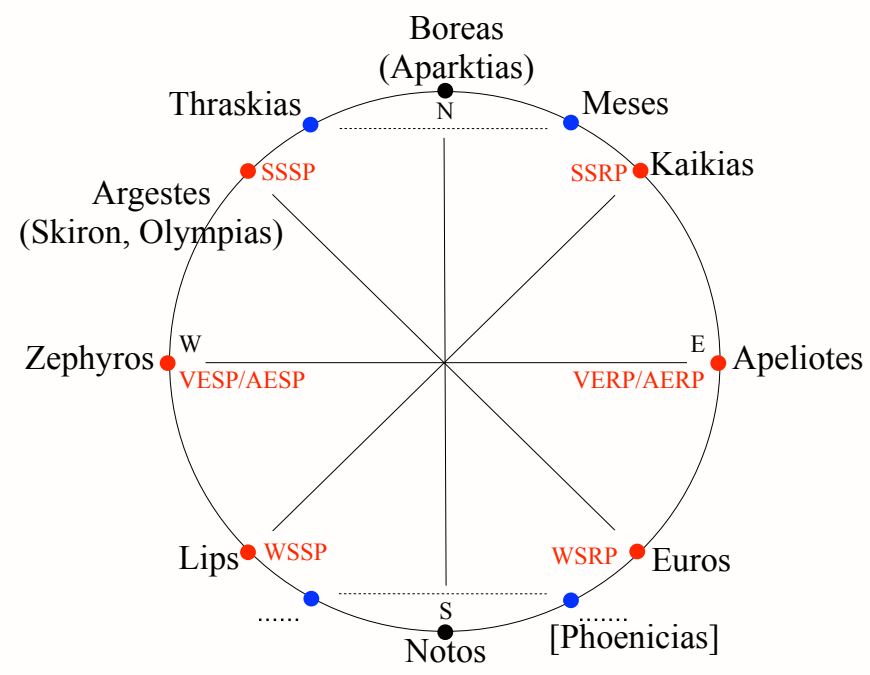

Figure 1. Aristotle's Wind-Rose [De caelo 2.6]

\section{The winds and their directions}

So, let us turn to the question, How is one to specify the directions of the winds? For Aristotle [Meteor. 2.6] and the author of the Пврі кó directions are to be specified with reference to the Sun's rising and setting points at the observer's horizon, when the Sun is at the cardinal points of its annual course through the heavens. These cardinal points are its positions on the days of solstice and equinox. Thus, for observers at less than lat. $66.5^{\circ}$ to the north or south, there are, on the eastern horizon, the summer solstitial, the vernal/autumnal equinoctial, and the winter solstitial rising points; and, on the western horizon, there are the summer solstitial, the vernal/autumnal equinoctial, and the winter solstitial setting points. Now, the directions to these points on the observer's horizon are not to be identified by points on the compass, as Forster [1913] does. The reason, as Furley recognized $[1978,366 \mathrm{n} a]$, is that the solstitial rising and setting points are not fixed for all observers but vary from horizon to horizon, that is, with the observer's latitude [see Table 1; Appendix, p. 17]. In fact, for observers at latitudes greater than $66.5^{\circ}$ to the north or south, the Sun does not even cross the horizon on the day of solstice.

Thus, in Meteor. 2.6, when Aristotle offers a graphical representation of the winds [see Figure 1], this representation, which constitutes a wind-rose, involves marking out the horizon of some arbitrary observer in the northern inhabited lands by noting the Sun's cardinal rising and setting points during 
its annual course. As a refinement of the wind-rose offered in 2.6, Aristotle distinguishes the observer's real and ideal horizons, and remarks that both can be marked out in the same way. ${ }^{7}$ Still, Aristotle gives no indication that this division obtains for only those horizons in which the Sun rises and sets on the day of solstice; or that, while the divisions in the real and ideal horizons are made in the same way, that is, with reference to the same cardinal points, the positions of the solstitial rising and setting points on the horizon vary with latitude. The same holds true as well of points on the horizon at or near the ever-visible circle-these are the small, solid blue circles in Figure 1, p. 5-in that the location of this circle varies with latitude as well [Meteor. 2.6, 363b27-364a4].

Nevertheless, this is not a critical problem: what it means is that one must take care in interpreting Aristotle's account. His causal theory of the Sun's action throughout the year on the Earth's two exhalations, the moist (vapor) and the dry, the latter being the source and nature of wind [Meteor. 2.4-5], suffices to guarantee that his wind-rose will hold, but only for those observers at latitudes greater than $23.5^{\circ}$, if Notos is to be a southerly wind [Meteor. 2.5, 362a31-b1o], but yet no greater than $66.5^{\circ}$, the latitude where the wind-rose pattern ceases to hold.

There is no saying if the author of the Vent. situs recognized the nature and limitations of Aristotle's wind-rose. Still, we can see that he takes a different approach. Rather than use the Sun's cardinal rising and setting points for reference, he identifies the directions of winds by pointing to such geographical features as mountains, promontories, plains, and rivers, as well as to such political features as countries and their peoples. The typical entry in his catalog is of this sort:

Topic wind.

Alternative name for this wind, $N$, given in $X$ (a town, country, town, or island), since it blows from a geographical or political feature $N^{\prime}$.

7 See Aristotle, Meteor. 2.6, 363a25-30:

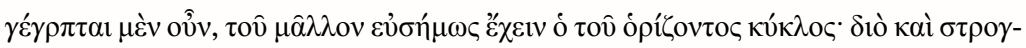

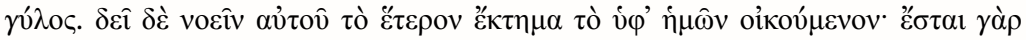

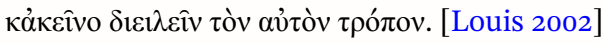

Now, the circle of the horizon has been drawn for the sake of greater claritywhich is why it is round. Although it is right to consider the [land] inhabited by us as a section different from [this horizon circle], it certainly will be possible to divide that [section] too in the same way.

Cf. Forster 1913, ad loc. 
It is striking that a good number of the entries in the Vent. situs are concerned to state the connection between the alternative name $N$ for the topic wind and the geographical or political feature $N^{\prime}$. In some cases, such etymologizing is unexceptional: thus, for instance, the derivation of the name "Pagreus" from the fact that it blows from the Pagrica mountains, or of the name "Kaunias" from the fact that it blows from the town, Kaunos [Caunus]. ${ }^{8}$ In others,

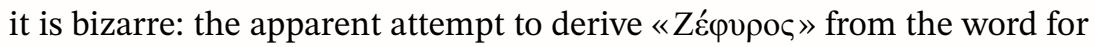
evening and the west, « $\dot{\varepsilon} \sigma \pi \varepsilon \dot{\varepsilon} \rho \alpha »$, is a case in point. ${ }^{9}$

But this brings to the fore the problem of understanding the topic winds themselves. These are pretty much the same as those found in Meteor. 2.6

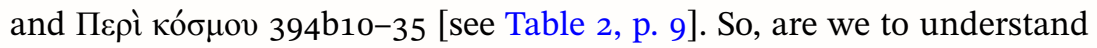
them in the same way, that is, as winds also defined in some wind-rose?

Plainly, it would be a mistake to hold that the topic winds listed in the Vent. situs, though perhaps taken from those mentioned in some wind-rose, are understood to be specified in a wind-rose. After all, the Vent. situs neither alludes to nor needs a horizon circle. In fact, the diagram mentioned at its

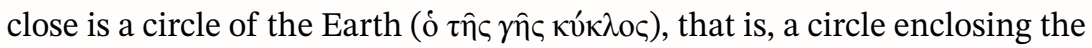
inhabited world. This circle cannot be a horizon. After all, there is no single horizon circle that includes parts of Asia Minor as well as northern Africa. That is, there is no observer on Earth who can see these lands without changing longitude and latitude. But what if the author presupposes a standard horizon, say, the one at lat. $55.67^{\circ}$, in which the summer solstitial rising point lies due northeast [see Table 1, p. 4], or a standard pattern that has the winds spaced equally at $30^{\circ}$ intervals between the orthogonal north-south and east-west directions ? $^{10}$

Well, consider D'Avella 2007, 222.1-8 [973a1-8], where it is asserted that Borras has the names:

(a) "Pagreus" in Mallos $\left(\approx\right.$ long. $35 ; 30^{\circ}$, lat. $\left.36 ; 45^{\circ}\right)$ because it blows from the Pagrika mountains ( $\approx$ long. $36 ; 15^{\circ}$, lat. $\left.36 ; 20^{\circ}\right)$, and

${ }^{8}$ See p. 11below on transliteration and the presentation of place-names.

9 Such etymologizing may indicate a Hellenistic provenance and raises the question, Was the author of the Vent. situs a Stoic? There certainly were Stoics who took Aristotle's texts as important points of departure in the late second and first centuries $\mathrm{BC}$ [see Falcon 2012, 2015, and 2016]. Posidonius himself is reported to have written a commentary on the Meteorologica [Edelstein and Kidd 1989, fr. 18: cf. frr. 137a-b]. Furthermore, the Stoic school was in general given to using etymology to show the nature of things.

10 This pattern figures in Ptolemy's Geographia: cf. Berggren and Jones 2000, 15. 
(b) "Kaunias" in Rhodes ( $\approx$ long. $28 ; 00^{\circ}$, lat. 36;10 $)$ because it blows from Kaunos [Caunus] ( $\approx$ long. $28 ; 35^{\circ}$, lat. $36 ; 50^{\circ}$ ).

Mallos is roughly $45^{\prime}$ to the west of the Pagrika and roughly $25^{\prime}$ to the north, which means that the Pagreus is a southeasterly to easterly wind [Talbert 2000, 67 B3-C4]. Rhodes, however, lies roughly $35^{\prime}$ to the west of Caunus and roughly $40^{\prime}$ to the south, thus making the Kaunias a northeasterly wind [Talbert 2000, 60 F3-G3, 65 A4, $1 \mathrm{I}_{3}$ ]. So, if we take for granted at the outset that Borras is a northerly wind, it would follow that the Vent. situs is in error. Indeed, there will prove to be numerous errors of this sort. But all of them, I suggest, will be no more than a scholarly artifact of choosing the wrong starting point for interpretation.

So, let us not attribute either error to the author of the Vent. situs. That is, instead of reading Vent. situs as a supplement to some wind-rose, let us understand it as a report of the terms used by diverse peoples in naming the winds characteristic of different times of year at their locations. Specifically, my working hypothesis is that:

(a) the names of the 10 topic winds are selected in the light of some variant of the wind-rose [see Table 2];

(b) these topic winds are differentiated mainly by when they blow during the year and, perhaps, by the weather that they bring, something that the author does not explain but takes for granted, perhaps because it is common knowledge; ${ }^{11}$

(c) the winds listed under a topic wind are thus to be understood as winds that blow at roughly the same time of year as the topic wind and, perhaps, bring the same kind of weather; ${ }^{12}$

(d) the winds so listed need not have the same direction; ${ }^{13}$

(e) one of the author's aims is to explain, whenever he can, the name of a listed wind in terms of the name of where it comes from;

11 As Aristotle indicates, while the topic winds do not always bring the same kind of weather, there is a general tendency for this [Meteor. 364a4-24, b3-365a1: cf. Пвpi

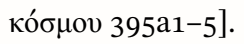
See Aristotle, Meteor. 2.6, 364a27-32, for the remark that winds coming from different directions that are not opposite may blow at the same time.

13 Indeed, the same wind need not always have the same direction [Meteor. 2.6, 364b12-

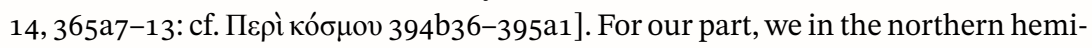
sphere might explain this phenomenon by reference to the typical course of a seasonal, cyclonic weather-system, that is, a large weather-system rotating counterclockwise. 


\begin{tabular}{|c|c|c|}
\hline $\begin{array}{c}\text { Aristotle } \\
\text { Meteor. } 2.6\end{array}$ & 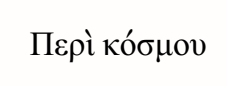 & $\begin{array}{l}\text { Ventorum situs } \\
\text { Topic Winds }\end{array}$ \\
\hline $\begin{array}{c}\text { Boreas } \\
\text { (Aparktias) }\end{array}$ & Aparktias & Borras \\
\hline Meses & Boreas & $\ldots \ldots . . .^{a}$ \\
\hline Kaikias & Kaikias & Kaikias \\
\hline Apeliotes & Apeliotes & Apeliotes \\
\hline Euros & Euros & Euros \\
\hline [Phoenicias] $^{\mathrm{b}}$ & Euronotos & Orthonotos ${ }^{\mathrm{c}}$ \\
\hline Notos & Notos & Notos \\
\hline$\ldots \ldots . . .^{d}$ & $\begin{array}{l}\text { Libanotos } \\
\text { (Libophoenix) }\end{array}$ & Leukonotus \\
\hline Lips & Lips & Lips \\
\hline Zephyros & Zephyros & Zephyros \\
\hline $\begin{array}{c}\text { Argestes } \\
\text { (Skiron, Olympias) }\end{array}$ & $\begin{array}{c}\text { Argestes } \\
\text { (Olympias, Iapyx) }\end{array}$ & Iapyx \\
\hline Thraskias & $\begin{array}{c}\text { Thraskias } \\
\text { (Kirkias) }\end{array}$ & Thraskias \\
\hline
\end{tabular}

a "Meses" does not actually have its own entry. It is only listed as an alternative name for Borras. Forster [1913, ad $972 \mathrm{a} 4$ and $\mathrm{n} 1$ ] assumes that Vent. situs describes a wind-rose and proposes that Meses is the missing topic wind.

$\mathrm{b}$ This is a purely local wind.

c See p. 14 n 24 below.

d Aristotle maintains that there really is no wind contrary to Meses.

Table 2. Greek wind-names

The names in columns 1, 2 explicitly belong to a wind-rose; and the names in column 3 are in the order of their occurrence, assuming the omission of a wind after Borras [see note a].

(f) the disagreements that the author indicates about the topic wind under which a given named wind is to be placed are but indications of differences in linguistic usage; and

(g) the graphical representation mentioned at the close of Vent. situs amounted to a crude, composite weather-map showing the seasonal winds in different parts of the inhabited world in a typical year. 
Finally, to develop this working hypothesis, I must also assume that

(h) the author had (access to) reliable practical knowledge of the directions from the locales that he mentions to the places named as sources of wind there; and

(i) modern inferences about geographical directions on the basis of archaeological evidence of the places as identified in Talbert 2000 are warranted.

One might imagine that it would be better to proceed in the light of ancient geographical knowledge. But it was not until the second century AD, when Ptolemy's Geographia presented the requisite theoretical basis for mapmaking in the modern sense and supplied a gazetteer, that it was even possible either to represent the inhabited world graphically or simply to locate a place in a way that was both precise and accurate. Moreover, even if the data of Ptolemy's treatise were an accurate guide to the state of our author's own geographical knowledge, thus allowing us by comparison with modern maps to detect any errors that he makes about the directions that the winds come from-recall that his date is unknown and that Ptolemy's work may thus not be pertinent-the gazetteer does not mention many of the places that figure in the Vent. situs. ${ }^{14}$ Consequently, the best we can do is to assume that the author is correct about the directions that he identifies and that atlases such as Talbert 2000 are the best means available of determining them.

\section{A Hellenistic weather-map}

Readers will, of course, decide for themselves whether the Vent. situs is a lexical report that was, or can be, cast as an early kind of weather-map, by considering the text closely in relation to what is known today of places in the ancient world. But, if my the argument is correct, then we may infer that:

(a) since the Vent. situs is to be viewed as a proto-typical weather-map, it is unlike the accounts of the winds found, for example, in Aristotle, Meteor. 2.6, the anonymous Пврі кó $\sigma \mu o v$, and even Strabo, Geog. 1.2.21.

Moreover, we may now raise the question whether

(b) the attention to linguistic usage and etymology in the Vent. situs signals a rejection of the causal theory advanced by Aristotle in Meteor. 
2.4-5 in favor of the thesis that to understand the nature of the winds it suffices to understand their names, that is, why the winds have the names that they have.

Clearly, there is a need to re-assess the claims that the Ventorum situs et nomina is a Peripatetic work that draws on Aristotle's writings-perhaps

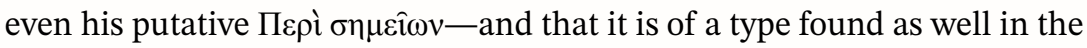

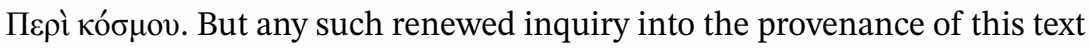
I will leave to others.

\section{The text}

For the Greek text here translated, though I have consulted Bekker 1831, Rose 1886-Rose printed the same version three times (1863, 1870, 1886) — and Apelt 1888, which mostly follows Rose 1886, I have based my translation on the edition recently prepared by Victor D'Avella [2007], recording D'Avella's lineation in the left margin and Bekker's [1831, 973] in the right.

I have used the following sigla in the footnotes to the translation as a means of simplifying the presentation of the Greek text itself:

$\begin{array}{ll}\text { Apelt } 1888 & \text { A } \\ \text { Bekker } 1831 & \text { B } \\ \text { Rose } 1886 & \text { R }\end{array}$

\section{Transliteration}

The problem of how to present the numerous place-names in this text is real. One approach is simply to transliterate the Greek, a practice followed mostly in D'Avella 2007, 223, 225 and Federspiel and Levet 2018, for example. Another would be to latinize these place-names, as in Forster 1913, Hett 1936, and Furley 1978. Yet another would be to follow the policy for placenames adopted in the Barrington Atlas of the Greek and Roman World, by transliterating Greek forms in all instances except when there is a Latin form available and this form may be regarded as more familiar [Talbert 2000, xxv]. My solution is a hybrid that accommodates readers wishing to locate the places mentioned in the Vent. situs. Thus, while I have as a rule transliterated the terms for the winds and places from the Greek, I have inserted beside them in brackets the Latin name under which they may be found in the Barrington Atlas when this name differs from the transliterated Greek. The exceptions are "Crete", "Italy", "Rhodes", and "Sicily"; rather than transliterate the Greek in these instances, I have translated it and enclosed the terms in the Atlas for these places alongside in brackets. 


\section{TRANSLATION}

The Directions and Names of the Winds

from Aristotle's Writings on Signs*

In Mallos, this is Pagreus since it blows from great heights, that is, from two mountains lying alongside one another that are called the $\mid$ Pagrika [Pagrica]. ${ }^{2}$ In Kaunos [Caunus], it is Meses. In Rhodes [Rhodos], it is Kaunias since it blows from Kaunos, disturbing their har || bor, Akanias. ${ }^{3}$ In Olbia, the one by Magydos of Pamphylia, it is Idyreus since it blows from the island which is called Idyris. ${ }^{4}$ Some, among whom are also the Lyrnatians, the ones in Phaselis, ${ }^{5}$ think that [the Idyreus] is Borras. ${ }^{6}$

| Kaikias.

In Lesbos, this is called Thebanas, since it blows from the $\|$ plain of Thebe ${ }^{7}$ [Thebai], the [plain] above the Elaitic Gulf of Mysias. It disturbs the harbor

* On this subtitle, see section 2, p. 3above.

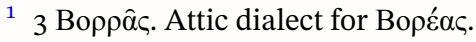

2 The Pagreus is a southeasterly to easterly wind [Talbert 2000, $67 \mathrm{~B}_{3}-\mathrm{C}_{4}, 1 \mathrm{~K}_{3}$ ].

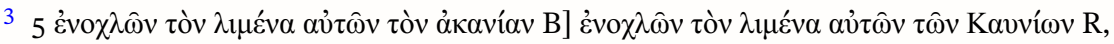
A (disturbing the harbor of the Kaunians themselves). See Goh and Schroeder 2015, s.v.'Aкavíac. The Kaunias is a northeasterly wind [Talbert 2000, 65 A4, 1 I3].

4 Talbert 2000, 65 E4 queries whether there was a town to the south of Olbia and Magydos called Idyros and a river Idyros nearby. No island named Idyris/Idyros has been identified yet.

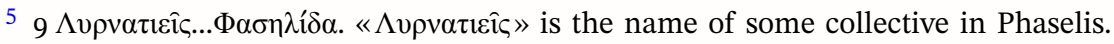
Note that Talbert 2000, 65 E4 queries whether an island to the north of Phaselis (and the putative Idyreis) but to the south of Olbia was named Lyrnateia.

6 This supports the author's inclusion of the Idyreus under the topic "Borras". The direction of the Idyreus, however, cannot be determined because the location of the island Idyris is not known.

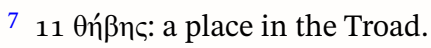


of the Mitylenians, especially [the temple] of [Apollo] the Protector of Flocks. ${ }^{8}$ But among some it is Kaunias, which others think is Borras. ${ }^{9}$ Apeliotes.

15 In Tripolis, the one of Phoinike [Phoenice], ${ }^{10}$ this $\mid$ is called Potameus. It blows out of a level plain which is like a great threshing-floor and is sur $\|$ rounded by the Libanos [Libanus] and Bapuros mountains. ${ }^{11}$ For this reason, it is, in fact, called Potameus. ${ }^{12}$ It disturbs [the shrine] of Poseidon. ${ }^{13}$ In the Gulf of Issos [Issicus Sinus] and around Rhossos [Rhosos], it is Syriander. It blows from the Gates of Syria [Syrii Pulai], which the Tauros [Taurus] and Rhosian mountains demarcate. ${ }^{14}$ In the | Gulf of Tripolis, it is Marseus || after the village of Marsos. ${ }^{15}$ In Prokonnesos [Proconnesus], Teos, Crete [Creta], Euboia [Euboea], and Kyrene [Cyrene], it is Hellespontias. It especially disturbs the harbor, Kapheres, of Euboia and the harbor of Kyrene, which is called Apollonia. It blows from the Hellespont. ${ }^{16}$ In Sinope, it is

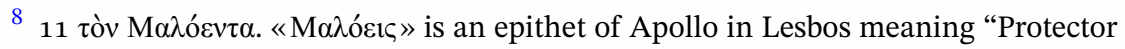
of Flocks" [cf. Thucydides, Hist. 3.3.3] and may also designate his temple there (scil.

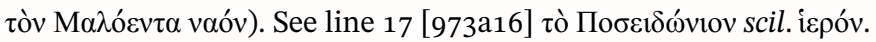

The Thebanas is a southerly wind [Talbert 2000, 61 E2, 56 C3, and 1 I3].

9 The author thus notes that the wind called Kaunias falls under both "Borras" and "Kaikias". This sentence is not misplaced, as Forster [1913, n 3 ad 973a24-25] supposes.

$1014 \tau \hat{\eta ิ ৎ ~ Ф о เ v ı к ิ ি ৎ: ~ s c i l . ~ A s i a t i c ~ P h o e n i c i a . ~}$

11 There is no entry for the Bapuros mountains in Talbert 2000. The Potameus is a southerly to southeasterly wind [Talbert 2000, 68 A5, 69 C2, 1 K4].

12 16-17: the etymology here is not explained. Forster [1913, $\mathrm{n}_{3}$ ad 973a16] speculates that the plain may have been called Potamos.

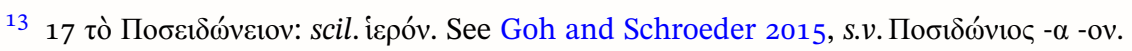
This shrine or temple is, presumably, in Tripolis. See line 11 [973a11].

14 The Gulf of Issicus is to the north of Rhossos, which would make the Syriander a southerly wind. The Gates of Syria, however, are to the east and slightly north of Rhosos, which would mean that the Syriander is more easterly.

15 There is no entry for Marsos in Talbert 2000.

16 Hellespontias is a northerly to northeasterly wind [Talbert 2000, 57 B3 and 6, E6; $\left.38 \mathrm{C}_{1} ; 1 \mathrm{I}_{3}-4, \mathrm{H}_{2}-3\right]$. Prokonnesus, however, is either a town or an island in the Propontis and thus to the northeast of the Hellespont. Thus, the Hellespontias there would be southwesterly. 
Berekyntias because it blows from | regions in Phry || gia. ${ }^{17}$ In Sicily [Sicilia], it is Kataporthmia because it blows || from the strait. ${ }^{18}$ Some think that it is Kaikias and call it Thebanas. ${ }^{19}$

Euros.

In Aigai [Aigai(ai)], the one in Syria, this is called Skopeleus after the cliff (skopelos) of Rhossos [Rhosos]..$^{20}$ In Kyrene [Cyrene], it is Karbas after | the foreigners || in Phoinike [Phoenice], ${ }^{21}$ which is why some call it Phoinikias as well..$^{22}$ There are some who also think that it is Apeliotes. ${ }^{23}$

Orthonotos. ${ }^{24}$

Some designate this Euros; and others, Amneus.

Notos.

Among all [peoples], it is called the same. Its name is on account of its being

17 The etymology of "Berekyntias" is left unexplained. The Berekyntias is a northwesterly wind [Talbert 2000, 87 A2, 1 I2-K2].

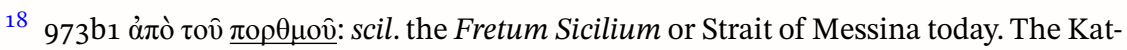
aporthmia is a northeasterly wind. [Talbert 2000, $1 \mathrm{~F}_{3}-\mathrm{G}_{3}$ ].

19 The author thus indicates some controversy about whether the Kataporthmia should be listed under "Kaikias" and identified as Thebanas or under "Apeliotes".

20 The Skopeleus is a southerly wind [Talbert 2000, 67 B3-4, $1 \mathrm{~K}_{3}$ ].

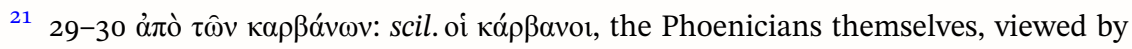
the author as foreigners/barbarians [cf. Forster 1913, ad loc; Goh and Schroeder 2015, s.v. кá $\rho \beta \alpha v o \varsigma-\eta-o v]$. In the next sentence, it is said that this wind is also Phoinikias, the wind from (Asiatic) Phoenicia. Apparently, the winds could be named after political features of the inhabited world and not just geographical ones.

${ }^{22}$ The Karbas/Phoinikias is an easterly to northeasterly wind [Talbert 2000, 67 B3-C2, $\left.1 \mathrm{H}_{4}-\mathrm{K} 4\right]$.

23 That is, some would think that the Karbas/Phoinikias should be listed under "Apeliotes".

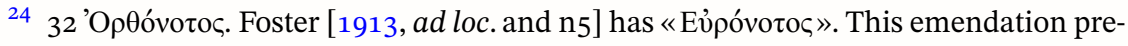

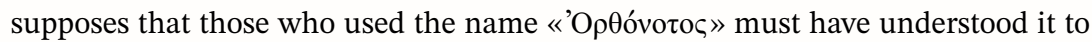
mean "Due South", and thus fails to distinguish how a word is formed and its usage or what it actually means in practice. Federspiel and Levet $[2018,33]$ evince the same failure when they claim that the author does not provide an etymology for "Aparktias" and "Apeliotes" because it was obvious that the former comes from the "Арктос (Ursa Major)—scil. from where it rises and sets-and the latter, from the (rising) and "Apeliotes", neither etymology identifies a geographical or political feature on Earth and so including them would be out of character. 
productive of illness and on account of its being rainy-in both senses, "notos". ${ }^{25}$

35 Likewise || Leu | conotos.

Its name is from a property since it makes [the sky] clear.... ${ }^{26}$

Lips.

This [wind has], in fact, this name after Libya, from where it blows. ${ }^{27}$

Zephyros.

This [wind has], in fact, this name on account of its blowing from the west. The west (evening?).... ${ }^{28}$

Iapyx.

In Taras [Tarentum], this is Skylletinos after the place Scyllantion [Scylletium]. ${ }^{29}$ In || Dorylaion, the one of Phyrygia, it is, in the words of some, ${ }^{30}$ 40 Pharangites since | it blows from some one of the canyons [pharanges] in Pangaion. ${ }^{31}$ Among many, it is Argestes.

Thrakias.

In Thrakia [Thracia], it is Strymonias since it blows from the river Strymon. ${ }^{32}$ But in the Megarid [Megaris], it is Skirron after the Skirronian Rocks. ${ }^{33}$ In

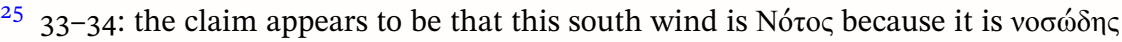
or productive of vóøoc (illness) and because it is vó

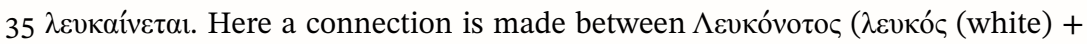

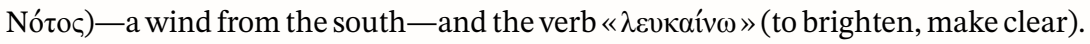
The Leukonotos is a wind that clears the sky.

${ }^{27}$ Lips is a southerly to southwesterly wind, assuming locations ranging from Italy in the west to Phrygia in the east [Talbert 2000, $1 \mathrm{H}_{4}-\mathrm{I}_{4}$ ].

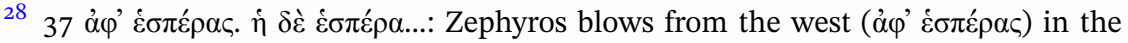

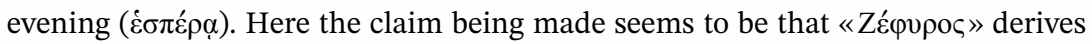
from «ं் $\sigma \pi \dot{\varepsilon} \rho \alpha »$.

29 The Skylletinos is a southwesterly wind [Talbert 2000, 46 E4, 1 G2-3].

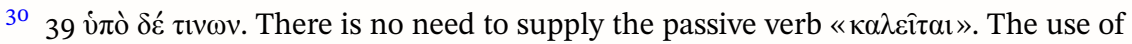
« $\tilde{\pi}$ ó + genitive with intransitive verbs to indicate agency goes back to Homer.

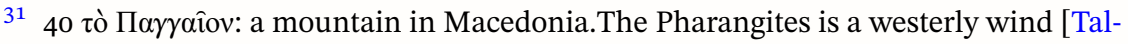
bert 2000, $\left.62 \mathrm{E} 2,51 \mathrm{C}_{3}, 52 \mathrm{~B} 4-\mathrm{H}_{4}, 1 \mathrm{I} 2-\mathrm{J}_{3}\right]$.

32 The Strymonias is a westerly to southwesterly wind [Talbert 2000, 51 B2].

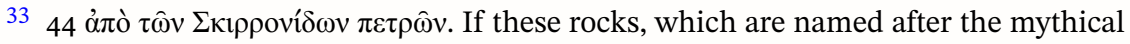

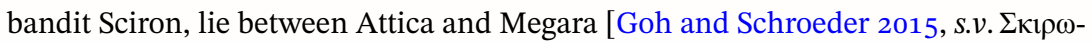
ví -ífoc], then the Skirron would be an easterly wind. Given their association with 
from Kirkaion. ${ }^{34}$ In Euboia [Euboea] and Lesbos, it is Olympias; its name is after the Olympos [Olympus] of Pieria. It irritates the people of Pyrrha. ${ }^{35}$ I have also drawn for you their locations, how they lie and blow, by drawing the circle of the Earth, ${ }^{36}$ so that $\|$ they may be set before your eyes as well.

| End of the names for winds.

\section{Acknowledgment}

I am grateful to Robert Hannah for his comments on an earlier draft of this article. The errors that remain are mine, of course. Further comments and suggestions from readers will be most welcome indeed.

the Megarid, however, and the route traveled along its southern coast, it seems possible that they were between Megara and Corinth, which, in some quarters of the Megarid, would make the Skirron a westerly to southwesterly wind.

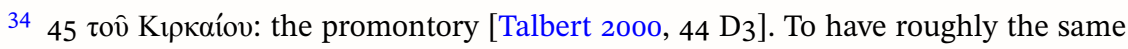
direction in Italy and Sicily, the Kirkias would have to be northwesterly [Talbert 2000, 44 D3, 1 E2-3].

35 The Olympias would seem to be northwesterly to westerly [Talbert 2000,50 B4; 1 $\mathrm{H} 2-3]$.

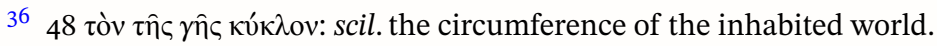


APPENDIX

THE SUN'S ORTIVE AMPLITUDE AT SOLSTICE

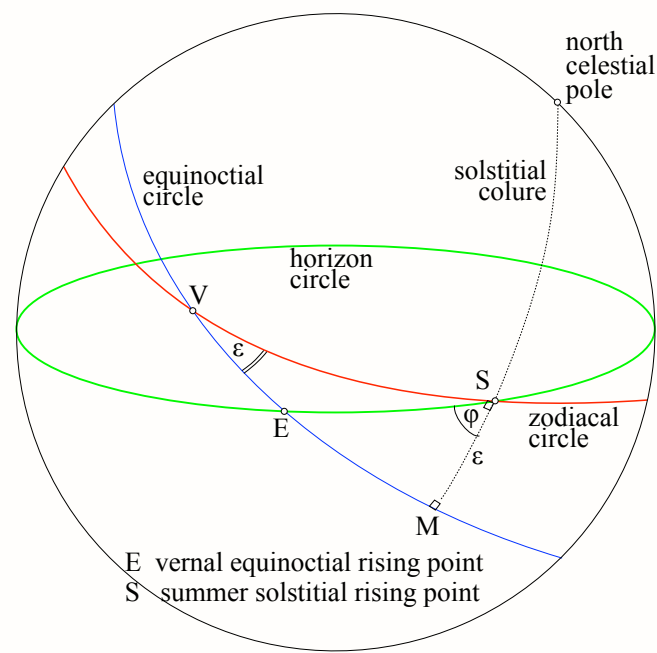

Figure 2. The ortive (rising)

amplitude of the summer solstitial point

Consider $\triangle E M S$, a spherical triangle on the unit-sphere on which all arcs are arcs of a great circle. The ortive amplitude of the Sun's rising point on the day of summer solstice is $E S$, the distance from the vernal equinoctial rising point $E$ to the summer solstitial rising point $S$.

Since the vernal equinoctial point $V$ on the celestial equator is a pole of the solstitial colure (the meridian circle through the poles of the zodiacal circle, the poles of the equinoctial circle, and the solstitial points), arc $V M=$ arc $V S=90^{\circ}$. Therefore, since $\angle M V S=\varepsilon$, where $\varepsilon$ is the obliquity of the zodiacal circle to the equinoctial circle $\left(\approx 23.5^{\circ}\right)$, arc $M S=\varepsilon$.

Since $\angle E S M=\varphi$, where $\varphi$ is the latitude of the horizon circle (scil. the elevation of the north celestial pole above this circle),

$$
\sin E S=\frac{\sin \varepsilon}{\cos \varphi}
$$

then

$$
E S=\arcsin \left(\frac{\sin \varepsilon}{\cos \varphi}\right) .
$$

The distance from the equinoctial rising point to the winter solstitial rising point is the same. ${ }^{37}$ 


\section{BIBLIOGRAPHY}

Primary sources

Aristotle. Meteorologica. See Louis 2002.

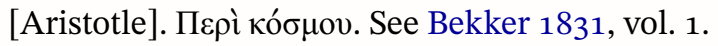

[Aristotle]. Ventorum situs et nomina. See D'Avella 2007.

Ptolemy. Geographia. See Nobbe 1843-1845.

Strabo. Geographica. See Radt 2002.

Secondary sources

Apelt, O. 1888. Aristotelis quae feruntur, De plantis, De mirabilibus auscultationibus, Mechanica, De lineis insecabilibus, Ventorum situs et nomina, De Melisso Xenophane Gorgia. Leipzig.

Bekker, I. 1831. Aristoteles graece. vol. 2. Berlin.

Berggren, J. L. and A. Jones. 2000. Ptolemy's Geography: An Annotated Translation of the Theoretical Chapters. Princeton, NJ/Oxford.

D’Avella, V. 2007. See Sider and Brunschön 2007, 221-225.

Edelstein, L. and I. G. Kidd. 1989. Posidonius: 1. The Fragments. Cambridge, UK.

Falcon, A. 2012. Aristotelianism in the First Century BCE. Cambridge, $\mathrm{UK} / \mathrm{New}$ York.

2015. "The Reception of Aristotle in Antiquity". https://www.oxfordhandbooks.com/view/10.1093/oxfordhb/9780199935314.001.0001/oxfordhb-9780199935314-e-54?rskey $=$ NlcCwC\&result $=1$.

2016. "Aristotelianism in the First Century BC”. Pp. 101-119 in A. Falcon, Brill's Companion to the Reception of Aristotle in Antiquity. Leiden/Boston.

Federspiel, M. and J.-P. Levet. 2018. Pseudo-Aristote. Du monde, Positions et dénominations des vents. Paris.

Forster, E. S. 1913. "Ventorum situs et appellationes”. See Ross 1913, 973ab.

Furley, D. J. 1978. [Aristotle]: On the Cosmos. Cambridge, MA/London, UK.

Geus, K. 2020. "Hellenistic Maps and Lists of Places”. Pp. 232-239 in A. C. Bowen and F. Rochberg edd. Hellenistic Astronomy: The Science in Its Contexts. Leiden/Boston. 
Goh, M. and C. Schroeder. 2015. edd. The Brill Dictionary of Ancient Greek by Franco Montanari. Leiden/Boston.

Hett, W. S. 1936. Aristotle: XIV. Minor Works. London, UK.

Lee, H. D. P. 1952. Aristotle: VII. Meteorologica. Cambridge, MA/London, UK.

Louis, P. 2002. Aristote. Météorologiques. 2 vols. Paris.

Nobbe, C. F. A. 1843-1845. Claudii Ptolemaei Geographia. 3 vols. Leipzig. Repr. Hildesheim, 1966.

Radt, S. 2002. Strabons Geographika. Band I. Prolegomena, Buch I-IV: Text und Übersetzung. Gottingen.

Rose, V. 1886. Aristotelis qui ferebantur librorum fragmenta. Leipzig.

Ross, W. D. 1913. The Works of Aristotle Translated into English. vol. 6. Oxford.

Sider, D. and C. W. Brunschön. 2007. edd. Theophrastus of Eresus: On Weather Signs. Leiden/Boston.

Talbert, R. J. A. 2000. Barrington Atlas of the Greek and Roman World. Princeton, NJ.

Van Brummelen, G. 2013. Heavenly Mathematics: The Forgotten Art of Spherical Trigonometry. Princeton, NJ. 